\title{
Correction to: Providing dental insurance can positively impact oral health outcomes in Ontario
}

Nevena Zivkovic ${ }^{1 *}$, Musfer Aldossri ${ }^{1}$, Noha Gomaa', Julie W. Farmer ${ }^{1}$, Sonica Singhal ${ }^{1}$, Carlos Quiñonez ${ }^{1}$ and Vahid Ravaghi

\section{Correction to: BMC Health Serv Res 20, 124 (2020) https://doi.org/10.1186/s12913-020-4967-3}

Following publication of the original article [1], the authors would like to add some information in the Competing interests section.

The updated content in the Competing interests is shown below:

Carlos Quiñonez receives consulting income for dental care related issues from Green Shield Canada. All other authors declare no competing interests.

The original article has been corrected.

\section{Author details}

${ }^{1}$ Dental Public Health, Faculty of Dentistry, University of Toronto, Toronto,

Canada. ${ }^{2}$ School of Dentistry, University of Birmingham, Birmingham,

England.

Published online: 12 March 2021

\section{Reference}

1. Zivkovic $\mathrm{N}$, et al. Providing dental insurance can positively impact oral

health outcomes in Ontario. BMC Health Serv Res. 2020:20:124.

The original article can be found online at https://doi.org/10.1186/s12913020-4967-3.

* Correspondence: nevena.zivkovic@mail.utoronto.ca

${ }^{1}$ Dental Public Health, Faculty of Dentistry, University of Toronto, Toronto, Canada

Full list of author information is available at the end of the article

(c) The Author(s). 2021 Open Access This article is licensed under a Creative Commons Attribution 4.0 International License, which permits use, sharing, adaptation, distribution and reproduction in any medium or format, as long as you give appropriate credit to the original author(s) and the source, provide a link to the Creative Commons licence, and indicate if changes were made. The images or other third party material in this article are included in the article's Creative Commons licence, unless indicated otherwise in a credit line to the material. If material is not included in the article's Creative Commons licence and your intended use is not permitted by statutory regulation or exceeds the permitted use, you will need to obtain permission directly from the copyright holder. To view a copy of this licence, visit http://creativecommons.org/licenses/by/4.0/ The Creative Commons Public Domain Dedication waiver (http://creativecommons.org/publicdomain/zero/1.0/) applies to the data made available in this article, unless otherwise stated in a credit line to the data. 